\title{
REINFORCING GRAMMATICAL STRUCTURE IN AUTHENTIC READING TEXTS
}

\author{
Genovaitė Snuviškienė
}

\author{
Vilnius Gediminas Technical University, Saulètekio al. 11, LT-10223 Vilnius, \\ e-mailvvka@vv.vtu.lt
}

The aim of this paper is to underline the importance of reinforcing grammatical structure in authentic reading texts in developing productive knowledge of the considered pattern.

The provided activities are directed towards the reinforcement of the highlighted structures functioning in an authentic context.

Keywords: grammatical structure, authentic reading text, reinforcement, productive knowledge.

\section{Introduction}

Reading is essential for the further development of the EFL in our country, where the possibilities of talking to the native speakers of English are limited. The more we read and listen, the more words we come to understand. But knowing the word means more than just its translated meaning or its synonyms (Snuviškiene 2004). Knowing grammatical patterns is one of the aspects of word knowledge.

According to M. Halliday's theory, grammar is a system which developed in order to help human beings operate in the world; which in some sense mirrors the world, and cannot be divorced from the social context. The new model of language learning sees the process as no different in principle from anything else (Low 2004). If you want to give a presentation to a conference, you make the ideas coherent, you identify the language to put the ideas over, and you practise your tenses and discourse markers. If you don't, the speech fails. In other words, system has to be studied or mastered before an effective communication can take place.

\section{Main part}

It has long been the practice for graded texts in coursebooks to contain numerous examples of the same grammatical structure in order to highlight the use of that structure in context. A graded text might contain several examples of the same grammatical structure. Typically, the text is then followed by comprehension questions that highlight the structure and various grammar-based practice exercises to reinforce its use.

In the case of authentic reading texts, however, the task of a teacher becomes a little trickier. It is rarely the case that such texts will have many examples of the same grammatical structure. The teacher will have to identify a structure that is useful for the learner. Therefore, he or she will have to produce exercises related to the example in the text to provide substantial practice of the particular structure.

Before taking to exercises, it is important that a chosen grammatical point be illustrated either by underlining it in the text or highlighting it in some other way. This has been successfully 
practised with some groups of Business Management. They had to underline the passive sentences in the article (Review 1999: 2-4) dealing with the macroeconomic environment of our country, for example:

\section{147 short-term measures and 31 middle-} term measures have already been fully implemented.

2. Efforts will be made to ensure that the measures provided ...cover all the acquis...

3. The Accession Partnership is the main guideline, ...objectives and priorities of which are being implemented through variety of programmes...

4. High investment growth rate was conditioned by ongoing restructuring...

5. The sale agreement is expected to be signed at the end of the year.

When looking at the meaning and use of the considered passives in more depth, the following questions were asked:

- Why is the passive voice used here?

- we are more interested in the event or action than the person who did it;

- with by when the agent is mentioned;

- the speaker wants to be objective in a scientific report;

- with verbs like believe, consider, expect (future reference), etc.

- Could the author use the active voice? If so, what would the sentence be like?

- Do you know that sometimes texts are abused with the passives?

Is this text abused with the passives?

Most technical writers use the passive sentences in their papers to sound intelligent, don't they?

Have you ever come across such a complicated text?

Then followed the questions related to tense and aspect, for example:

- What action does this type of present ( 1 and/or 3 ) indicate?
- Why is the action in the past (4) expressed with the simple past?

- Why is the present perfect (not the simple past) used in 1 ?

The grammar point having been illustrated, the teacher should give further practice of the particular structure. In our case of an authentic reading text, some exercises exploiting the passive structure were used for further related practice, for example:

1. Rewrite in the active voice, e. g.:

The list of objects slated for privatisation was approved by government.

The government approved the list...

2. Write further sentences from the given prompts, e. g.:

list/objects/slated for privatisation/ approve/ government

The list of objects slated for privatisation was approved by government.

3. Re-order the jumbled words to make accurate sentences, e. g.:

The integration radically was strategy for rewieved European.

The strategy for European integration was radically reviewed.

4. Choose the best from a series of options, e. g.:

The union of that country has adopted legislation designed to guarantee certain rights throughout the EU. You (to be/will be/have been/ are/were) given the same help to find work as nationals.

5. Write the endings of the sentences related to the text, e. g.:

The strategy for European integration was radically reviewed and... 
The sale of... will be completed, which... Efforts will be made to ensure that...

The authorities are believed to ..., etc.

\section{Conclusion}

Focusing on a grammatical structure or structures in an authentic texts such as newspaper articles, scientific papers, documents, etc., enables the students to see these structures functioning in an authentic context. However, it is rarely the case that an authentic text will have numerous examples of the same grammatical structure. Therefore, the teacher will need to develop exercises for further related practice in order to reinforce the chosen grammatical structure. While exploiting the particular structure, the teacher might either employ the text or go be- yond the actual text by using the same context. The produced exercises will certainly provide substantial practice of the particular structure and elaborate productive knowledge of the considered grammatical pattern.

\section{References}

Quarterly Macroeconomic Review of Lithuania. No 3, May. 1999.

Low, M. 2004. Stepping out of Chomsky's Shadow. Modern English Teacher.

Snuviškienè, G. 2004. "Reading-Based Second Language Vocabulary Acquisiting", in Tauta ir kalba: šiuolaikiniai sociolingvistinio ugdymo aspektai. Kaunas: Technologija, 194-196.

\title{
GRAMATINIŲ STRUKTŪRŲ İTVIRTINIMAS AUTENTIŠKOJE SKAITYMO MEDŽIAGOJE
}

\author{
Genovaitė Snuviškienè
}

Remiantis populiarejjančia moksline teorija, norint išmokti efektyviai bendrauti užsienio kalba, rekomenduojama mokytis konkrečios užsienio kalbos sistemos - ja studijuoti bei tobulinti, nes neįrodyta, kad kalba galima išmokti be „sąmoningo" mokymosi ("conscious” learning). Bet kalbos mokèjimas - tai ir gramatiniu struktūrų valdymas. Pasak ǐžymaus lingvisto M. Halliday, gramatika yra sistema, leidžianti žmonèms veikti pasaulyje.

Taigi studentams, besimokantiems anglu kalbos, labai svarbu tobulinti gramatikos žinias, ịtvirtinti gramatiniu struktūru vartojimo igūdžius. Tai ịmanoma integruojant kalbinès veiklos rūšis. Straipsnyje rekomenduojama skaitomame autentiškame specialybès tekste išskirti svarbias gramatines struktūras, atkreipiant demesi i ju prasmę, vartojimo ypatumus. Be to, rekomenduojama studentams pateikti pratimu pasirinktiems gramatinių struktūrų vartojimo igūdžiams ịtvirtinti. Čia pateikiami pratimu pavyzdžiai pasyvo struktūroms, esančioms autentiškame tekste, ịtvirtinti.

Reikšminiai žodžiai: gramatinè struktūra, autentiška skaitymo medžiaga, ittvirtinimas, igūdžiai ir žinios. 